DOI https://doi.org/10.18551/rjoas.2018-11.11

\title{
IMPLEMENTATION OF TAM IN EXPLAINING THE INTENTION TO REPURCHASE THE INTERNET PACKAGE IN MYTELKOMSEL APPLICATION
}

\author{
Nangi Iman Yosafat \\ University of Udayana, Bali, Indonesia \\ E-mail: imanyosafat00@gmail.com
}

\begin{abstract}
This study aimed to explain the effect of usability on the attitude of repurchase the internet package, to explain the effect of ease of use on the attitude of repurchase the internet package,to explain the effect of usability on the intention to repurchase an internet package and to explain the effect of ease of use on the intention to repurchase an internet package.The number of samples used was 60 respondents who repurchased the internet package through MyTelkomsel live in Denpasar City with the sampling technique using purposive sampling method. This research use PLS (Partial Least Square) analysis technique.The results showed that (1) usability has positive and significant effect on attitude, (2) ease of use has positive and significant effect on attitude, (3) usability negatively affects the intention torepurchase, (4) ease of use has positive and significant effect on the intention to repurchase, (5) attitude has positive and significant effect on the intention to repurchase. Based on the results of mediation of usability testing has a positive and significant effect on the intention to repurchase through the full mediation attitude and ease of use has positive and significant effect on the intention to repurchase through the partial attitudes (partial mediation). The implication of the results of this study is usability can be improved by paying attention to the dimensions of improving job performance thus the intention to repurchase the internet package in MyTelkomsel is getting increase, ease of use can be increased by taking into account the easy to get the system to do what he / she wants to do intention to buy again. Internet package in MyTelkomsel is getting increase, attitudes can be increased by paying attention to the dimensions of the cognitive components thus the intention to repurchase the internet package in MyTelkomsel is getting increase, the last intention to repurchase can be increased by paying attention to the dimensions of explorative interest.
\end{abstract}

\section{KEY WORDS}

Usability, ease of use, attitude, intention to repurchase.

The rapid development of the internet requires provider companies to provide the best and quality services in order to attract customers to use the services offered through the product of the provider company.In January 2016, the number of active internet users in Indonesia reached 88.1 million and 79.0 million for active social media users.the data was obtained from the We Are Social survey results; Global survey institutions related to digital data, social, trends and statistics of 2016.

Telkomsel operator has the largest network coverage in Indonesia, which provides network coverage that reaches more than $95 \%$ of Indonesia's population and Telkomsel is claimed to be the only Indonesian operator covering all countries, provinces and districts, both sub-districts from Sumatra to Papua. PT. Telkomsel has a slogan "begitu dekat begitu nyata". Through this slogan, it is hoped that Telkomsel will become the most mobile telecommunications service company with the highest number of customers and always prioritize the highest quality and availability of network capacity in providing the best service to its customers.

Behind its big name, Telkomsel also has various problems that become complaints of its customers, such as related to internet packages, telephone packages and internet networks or telephone. related to internet packages, Telkomsel has launched one of its applications, named MyTelkomsel. Based on a preliminary survey conducted on 100 customers, 65 customers complained that they were confused about the number of internet 
packages they had. Some even don't understand that the facilities provided by Telkomsel can be used by the customers themselves.

MyTelkomsel is a versatile application that comes with a new design and better user experience for Telkomsel services. One of the feature that can be use by the Telkomsel customers is to purchase credit or internet packages. But behind the big names and features of MyTelkomsel itself, it turns out there are still many customers who are reluctant to buy internet package at MyTelkomsel, and some even do not know what MyTelkomsel is and its uses. Therefore, the researcher wants to know how the influence or effect of TAM towards the intention of customers to purchase internet package through MyTelkomsel application.

Technology Acceptance Model (TAM) is used as the basis of various Rocker technology information system studies (2009). Ratuolivia (2012) explained that TAM is an information system theory that makes models about how users want to accept and use technology. According to Piriyakul et al. (2015) perceptions of usability also play a role in purchasing Telkomsel internet packages. Usability perception is defined as "the degree to which a person believes that using a particular system will improve his job performance". In Kamelia's study (2012), stated that the usability perception has positive and significant effect on attitude. In Lutfi et al study. (2013) stated that the ease perception of use has positive and significant effect on attitude. In Rendy and Santika study (2014) stated that the perception of usability has positive and significant effect on intention. Habibi and Zaki (2012) stated that the perception of usability has positive and significant effect on intention. However, different results come from Khakim and Kharisma Nur study (2012) stated that the perception of usability has negative and insignificant effect on intention. In Wahyuningtyas and Widiastuti study (2015) stated that the perceived ease of use had positive and significant effect on intention. This research was conducted based on two reasons: (1) the existence of research problems found in the field, and (2) there is a research gap that has been disclosed in the previous paragraph. The object of this research is MyTelkomsel Application as a versatile application that comes with new designs and better user experience for Telkomsel services.

\section{LITERATURE REVIEW}

Technology Acceptance Model (TAM) defines two perceptions of technology users who have an impact on their acceptance. TAM emphasizes user perceptions of "how is the system works for me" and "how easy is this system used" are two strong factors that influence the acceptance of technologyand is a fundamental determinant of user acceptance. The purpose of TAM is "to provide an explanation of computer acceptance determination which is generally able to explain user behavior in various end-user computing technologies and user populations".

According to Azwar (2010), attitude is a person's closed response to a stimulus or a particular object, which involves some factors such as opinion and emotion concerned (happy-unhappy, agree-disagree, good-bad and so forth).

The usability perception is a level where a person believes that a particular use of technology will improve the work performance of that person (Rocker, 2009). Basgoze and Ozer (2012) define the usability perception as a construct of one's trust that the use of a particular technology will be able to improve their performance.

The ease perception of use is a level where a person believes that technology is easy to understand. Basgoze and Ozer (2012) state that the easeperception of use of a technology is defined as a measure in which a person believesthat the technology can be easily understood and used. According Jogiyanto (2009) ease perception of use is defined as the extent to which a person believes that using a technology will be free from business.

Repurchase Intention is the intention to repurchase a product twice or more, both for the same and different products (Zeng et al, 2009). This repurchase includes 2 characteristics; intention and behavior. According to Regina et al. (2015) repurchase intention is a decision making process carried out by consumers after making a purchase of the product offered or needed by the consumer, when a consumer receives a positive 
response to previous actions, there will be reinforcement, with positive thinking on what they receive allows individuals to make repeated purchases.

Research Hypothesis:

$\mathrm{H}_{1}$ : Usability perception has significant positive effect on attitude;

$\mathrm{H}_{2}$ : Ease perception of usehas significant positive effect on attitude;

$\mathrm{H}_{3}$ : Usability perception has significant positive effect on the intention to repurchase;

$\mathrm{H}_{4}$ : Ease perception of usehas significant positive effect on the intention to repurchase;

$\mathrm{H}_{5}$ : Attitude has significant positive effect on the intention to repurchase.

\section{METHODS OF RESEARCH}

The population in this study is all the Telkomsel customers who repurchase internet packagein MyTelkomsel application. As a material consideration in determining the decision of at least one to three times the purchase, and is in the age range of 17 to 56 years and above, thus the population cannot be determined infinite. The criteria for determining the sample related to education is minimum high school or equivalent.

The number of samples in this study were 60 respondents from the entire area of Denpasar city, this was based on a good number of samples, that is $1-5 x$ the number of parameters estimated (Ferdinand, 2016:44). The criteria adjusted to this study resulted in a range of $(1-5) \times 15=15$ to 75 . The sample determination technique used in this study was purposive sampling technique. This means that anyone who is met by chance and meets the criteria can be used as a sample. The criteria referred to the respondents who live in Denpasar City and the respondents who use MyTelkomsel application and repurchase internet packages through MyTelkomsel for consideration in determining a decision at least one to three times.

\section{RESULTS AND DISCUSSION}

In this structural model,there are fouren dogenous (dependent) variables include:attitude $\left(\mathrm{Y}_{1}\right)$ and intention to repurchase $\left(Y_{2}\right)$. The coefficient of determination $\left(R^{2}\right)$ of each dependent variable presented in Table 1.

Table 1 - Evaluation Result of Goodness of Fit

\begin{tabular}{lll}
\hline No & Dependent variabel & $R$-square \\
1 & Attitude $\left(\mathrm{Y}_{1}\right)$ & 0,796 \\
2 & Intention to repurchase $\left(\mathrm{Y}_{2}\right)$ & 0,968 \\
\hline Calculation: $\mathrm{Q}^{2}=1-\left[\left(1-\mathrm{R}_{1}{ }^{2}\right)\left(1-\mathrm{R}_{2}{ }^{2}\right)\right]=0,988$ & \\
\hline
\end{tabular}

Source: Smart PLS 2.0 processed data, 2017.

Based on Table 1 above, the evaluation results of the structural model obtained the value of $Q^{2}$ is 0.988 . Thus, the results of this evaluation prove that the structural model has a goodness of fit model. This result can be interpreted that the information contained in the data is 98.8 percent can be explained by the model, while the remaining 1.2 percent is explained by errors and other variables that are not in the model.

Validation test results of the path coefficients on each path for direct effect and effect can be presented in the following Table 2 .

Table 2 - Direct Effect Testing Results

\begin{tabular}{lllll} 
No & Construct & Correlation coefficient & $t$ Statistics & Status \\
\hline 1 & Usability $\left(\mathrm{X}_{1}\right) \rightarrow$ Attitude $\left(\mathrm{Y}_{1}\right)$ & 0,590 & 5,966 & Accepted \\
\hline 2 & Ease of $U$ se $\left(\mathrm{X}_{2}\right) \rightarrow$ Attitude $\left(\mathrm{Y}_{1}\right)$ & 0,357 & 3,061 & Accepted \\
\hline 3 & Usability $\left(\mathrm{X}_{1}\right) \rightarrow$ Intention to repurchase $\left(\mathrm{Y}_{2}\right)$ & $-0,029$ & 0,560 & Rejected \\
\hline 4 & Ease of $U$ se $\left(\mathrm{X}_{2}\right) \rightarrow$ Intention to repurchase $\left(\mathrm{Y}_{2}\right)$ & 0,115 & 2,415 & Accepted \\
\hline 5 & Attitude $\left(\mathrm{Y}_{1}\right) \rightarrow$ Intention to repurchase $\left(\mathrm{Y}_{2}\right)$ & 0,914 & 15,054 & Accepted
\end{tabular}

Source: Data processed by Smart PLS 2.0. 
Usability $\left(\mathrm{X}_{1}\right)$ proved haspositive and significant effect on attitude $\left(\mathrm{Y}_{1}\right)$. This result is shown by the path coefficient that has positive value of 0.590 with $\mathrm{t}$-statistic $=5,966$ (tstatistic > 1.96), thus the hypothesis-1 $\left(\mathrm{H}_{1}\right)$ : usability has positive and significant effect on attitude can be proven. The ease of use $\left(X_{2}\right)$ has a positive and significant effect on attitude $\left(Y_{1}\right)$. This result is shown by the path coefficient that has positive value of 0,357 with $t-$ statistic $=3,061$ (t-statistic > 1.96). This result indicates that hypothesis-2 $\left(\mathrm{H}_{2}\right)$ : the ease of use has positive and significant effect on attitude proven empirically. Usability $\left(\mathrm{X}_{1}\right)$ has positive and significant effect on the positive intention to repurchase $\left(Y_{2}\right)$. This result is shown by the path coefficient that has positive value of $-0,029$ with $\mathrm{t}$-statistic $=0,560$ (t-statistic< 1.96). This result indicates that hypothesis-3 $\left(\mathrm{H}_{3}\right)$ : Usability has negative and significant effect on intention to repurchase cannot be proven. The ease of use $\left(X_{2}\right)$ has positive and significant effect on the positive intention to repurchase $\left(\mathrm{Y}_{2}\right)$. This result is shown by the path coefficient that has positive value of 0,115 with t-statistic $=2,415$ (t-statistic $>1.96$ ). This result indicates that hypothesis-4 $\left(\mathrm{H}_{4}\right)$ : the ease of use has positive and significant effect on intention to repurchase.Attitude $\left(Y_{1}\right)$ has positive and significant effect on the positive intention to repurchase $\left(Y_{2}\right)$. This result is shown by the path coefficient that has positive value of 0,914 with $\mathrm{t}$-statistic $=15,054$ (t-statistic $>1.96$ ). This result indicates that hypothesis-5 $\left(\mathrm{H}_{5}\right)$ : has positive and significant effect on intention to repurchase can be proven.

In testing the following hypothesis, the mediating role of attitude variable will be examined $\left(Y_{1}\right)$ on the indirect effect of usability $\left(X_{1}\right)$ and the ease of use $\left(X_{2}\right)$ on the intention to repurchase $\left(Y_{2}\right)$. The results of hypothesis testing of indirect effect in this study then were presented in the following Table 3.

Table 3 - Recapitulation of Test Results for Mediation Variables

\begin{tabular}{|c|c|c|c|c|c|c|}
\hline \multirow{2}{*}{ No } & \multirow{2}{*}{ Mediation of AttitudeVariable $\left(\mathrm{Y}_{1}\right)$ on: } & \multicolumn{4}{|l|}{ Effect } & \multirow{2}{*}{ Status } \\
\hline & & (a) & (b) & (c) & (d) & \\
\hline 1 & Usability $\left(\mathrm{X}_{1}\right) \rightarrow$ intention to repurchase $\left(\mathrm{Y}_{2}\right)$ & $\begin{array}{l}-0,029 \\
\text { (NoSig.) }\end{array}$ & 0,530 (Sig.) & $\begin{array}{l}0,590 \\
\text { (Sig.) }\end{array}$ & $\begin{array}{l}0,914 \\
\text { (Sig.) }\end{array}$ & $\begin{array}{l}\text { Full } \\
\text { Mediation }\end{array}$ \\
\hline 2 & The ease of use $\left(X_{2}\right) \rightarrow$ intention to repurchase $\left(Y_{2}\right)$ & $\begin{array}{l}0,115 \\
\text { (Sig.) }\end{array}$ & 0,422 (Sig.) & $\begin{array}{l}0,357 \\
\text { (Sig.) }\end{array}$ & $\begin{array}{l}0,914 \\
\text { (Sig.) }\end{array}$ & $\begin{array}{l}\text { Partial } \\
\text { Mediation }\end{array}$ \\
\hline
\end{tabular}

Attitude $\left(\mathrm{Y}_{1}\right)$ able to mediate significantly on the indirect effect of usability $\left(\mathrm{X}_{1}\right)$ towards the intention to repurchase $\left(Y_{2}\right)$. This result is shown if the effect of independent variable on mediating variable (c) and the influence of mediating variable on the dependent variable (d) is significant, the direct influence of the independent variable on the dependent variable on the model involves the mediating variable (a) non-significant, the direct influence of the independent variable on the dependent variable without involving the mediating variable (b) is significant, it is called as complete/full mediation. The results of this test determine that usability $\left(X_{1}\right)$ can affect the intention to repurchase $\left(Y_{2}\right)$ through attitude $\left(Y_{1}\right)$ which can be proven empirically. Based on these results, the more respondents understand the usability of MyTelkomsel application and they have good attitude toward this application, hence, the intention to purchase an internet package is getting increase. Other information that can be conveyed is the mediating effect of attitude variables $\left(Y_{1}\right)$ on the indirect effect of usability $\left(X_{1}\right)$ towards the intention of repurchase $\left(Y_{2}\right)$ is full mediation. This finding shows that the attitude variable $\left(Y_{1}\right)$ is a determining variable on the effect of usability $\left(X_{1}\right)$ towards the intention of repurchase $\left(\mathrm{Y}_{2}\right)$.

Attitude $\left(Y_{1}\right)$ is able to mediate significantly on the indirect effect of ease of use $\left(X_{2}\right)$ towards the intention to repurchase $\left(\mathrm{Y}_{2}\right)$. This result is shown if the influence of independent variable on mediating variable (c) and the influence of mediating variable on the dependent variable (d) is significant, the direct influence of the independent variable on the dependent variable on the model involving the mediating variable (a) is significant, and the direct influence of the independent variable on the dependent variable without involving the mediating variable (b) is significant, it is said to be a partial mediation variable. The results of this test determine that ease of use $\left(X_{2}\right)$ can affect the intention to repurchase $\left(Y_{2}\right)$ through attitude $\left(Y_{1}\right)$ able to be proven empirically. Based on these results can be interpreted, the 
more respondents understand the ease of use of MyTelkomsel application and respondents have a good attitude towards MyTelkomsel application, then the intention to repurchase the internet package is increasing. Other information isthe mediating effect of attitude variable $\left(Y_{1}\right)$ on the indirect effect of ease of use $\left(X_{2}\right)$ towards the intention to repurchase $\left(Y_{2}\right)$ is partial (parsial mediation). This finding shows that the attitude variable $\left(Y_{1}\right)$ is not a determinant variable on the effect of ease of use $\left(X_{1}\right)$ towards the intention to repurchase $\left(\mathrm{Y}_{2}\right)$.

In order to determine the overall effect for each relationship between the variables under study, a summary of the direct, indirect and total effects were presented in the following Table 4.

Table 4 - Calculation ofDirect, Indirect and Total effects

\begin{tabular}{lllll}
\hline No & Variable Relationship & Direct Effect & Indirect Effect & Total Effect \\
\hline 1 & Usability $\left(\mathrm{X}_{1}\right) \rightarrow$ Attitude $\left(\mathrm{Y}_{1}\right)$ & $0,590^{\mathrm{S}}$ & - & 0,590 \\
2 & Ease of use $\left(\mathrm{X}_{2}\right) \rightarrow$ Attitude $\left(\mathrm{Y}_{1}\right)$ & $0,357^{\mathrm{S}}$ & - & 0,322 \\
3 & Usability $\left(\mathrm{X}_{1}\right) \rightarrow$ intention to repurchase $\left(\mathrm{Y}_{2}\right)$ & $-0,029^{\mathrm{NS}}$ & 0,539 & 0,510 \\
& & & $\left(0,590^{\star} 0,914\right)$ & 0,326 \\
4 & Ease of use $\left(\mathrm{X}_{2}\right) \rightarrow$ intention to repurchase $\left(\mathrm{Y}_{2}\right)$ & $0,115^{\mathrm{S}}$ & $\left(0,357^{*} 0,914\right)$ & 0,441 \\
5 & Attitude $\left(\mathrm{Y}_{1}\right) \rightarrow$ intention to repurchase $\left(\mathrm{Y}_{2}\right)$ & $0,914^{\mathrm{s}}$ & - & 0,914 \\
\hline
\end{tabular}

Source: Data processed by Smart PLS.

The information obtained from Table 5.18 above is the mediating effect of attitude variable $\left(Y_{1}\right)$ on the indirect effect of usability $\left(\mathrm{X}_{1}\right)$ towards the positive intention to repurchase $\left(Y_{2}\right)$ more, iswith a path coefficient of 0.539 , compared to the indirect effect of ease of use $\left(X_{2}\right)$ towards the positive intention to repurchase $\left(Y_{2}\right)$ with the resulting path coefficient of 0.326 . Therefore overall the path of use $\left(X_{1}\right) \rightarrow$ attitude $\left(Y_{1}\right) \rightarrow$ intention to repurchase $\left(Y_{2}\right)$ larger with a total effect obtained is 0.510 , compared to the path of ease of use $\left(X_{2}\right) \rightarrow$ attitude $\left(Y_{1}\right) \rightarrow$ intention to repurchase $\left(Y_{2}\right)$ with a total effect of 0.441 . This finding shows a better use of making respondents feel satisfied with MyTelkomsel application thus it can increase the intention to repurchase the internet package in MyTelkomsel application.

\section{CONCLUSION AND SUGGESTIONS}

Usability has a positive and significant effect on attitude. This result means that the higher use of respondents to MyTelkomsel, attitude of respondents towards MyTelkomsel is getting better. Ease of use has a positive and significant effect on attitude. This result means that the higher ease of use of MyTelkomsel, attitude of respondents towards MyTelkomsel is getting better.

Usability has a negative and significant effect on repurchase intention. This result means that usability cannot affecting the intention to repurchase, the better use of respondents to MyTelkomsel is not necessarily to increase the intention to repurchase MyTelkomsel internet package. The findings of this study illustrate that usability is not a key determinant variable in increasing the intention to repurchase internet packages.

Ease of use has a positive and significant effect on the intention to repurchase. This result means that the higher ease of use of MyTelkomsel, attitude of respondents towards MyTelkomsel is getting better. The findings of this study illustrate that ease of use tends to be "clear and understandable, does not require a lot of mental effort, is easy to use, and easy to get the system to do what he / she wants to do" can increase the intentions torepurchase reflected in referential, explorative, transactional, and preferential interests.

Attitude has positive and significant effect on the intentions to repurchase. This result means that the better attitude of respondents towards MyTelkomsel, the intention to purchase MyTelkomsel internet package by the respondents is getting increase. The findings of this study illustrate that attitude which is reflected in cognitive, affective, and conative component scan increase the intentions to repurchase reflected in referential, explorative, transactional, and preferential interests. 
The scope of the research is only limited to Grapari Telkomsel Denpasar City, thus the results may have differences regarding to the perception or level of interpretation of each respondent in other regions. This study uses a cross-sectional time design or at a certain time point, but on the other hand this study observes the dynamics of the conditions that each period changes. Therefore, this research is important to be re-examined in the future.

\section{REFERENCES}

1. Azwar, S. 2010. Sikap Manusia Teori and Pengukurannya. Yogyakarta: Pustaka Pelajar.

2. Alfin Lutfi., Heru Susilo., and Mochhamad Al Musadieq.2013 Pengaruh Kemudahan Penggunaan Terhadap Kemanfaatan Pada Sikap Pengguna E-Learning.Jurnal Administrasi and Bisnis(JAB) Vol.6 No 2.pp 269-286.

3. Basgoze., Ozer Leyla., and Pinar. 2012, Effects Of Brand Credibility On Technology Acceptance Model: Adaption Of The Model To The Purchace Intention, International Journal Humanities And Social Science, Vol. 2 No 20.pp. 126-141

4. Ferdinand Augusty. 2016. Metode Penelitian Manajemen: Pedoman Penelitian untuk skripsi, Tesis and Disertai IImu Manajemen. Semarang: Universitas Diponegoro.

5. Habib Hanafi., Hadi., and Heru. 2013. Pengaruh Persepsi Kemanfaatan and Persepsi Kemudahan Website Ub Terhadap Sikap Pengguna Dengan Pendekatan TAM(Survei Pada Anggota Website www.Ub.Ac.Id Mahasiswa FIA Bisnis and Publik TA 2011-2012 Universitas Brawijaya Malang).Jurnal IImu Administrasi.Universitas Brawijaya Malang.Vol.9 No 1. pp 81-100

6. Ibna Kamelia. 2012. Pengaruh Manfaat and Kegunaan Yang Dirasakan Terhadap Sikap and Niat Pembelian Ulang Online Pada Phee Boutiq Jember (Studi Kasus pada Phee Boutiq Jember).Jurnal Akuntansi.FE Universitas Muhammadiyah Jember.Vol. 39.No. 12.pp 899-929

7. Jogiyanto, 2009.Sistem Informasi Keperilakuan. Edisi Revisi. Yogyakarta: Andi Offset.

8. Khakim.dan Kharisma Nur. 2012. Analisis Faktor-Faktor Yang Memepengaruhi Penerimaan and Niat Penggunaan Software Akuntansi MYOB Dengan Menggunakan Pendekatan Technology Acceptance Model (TAM). Jurnal Fakultas Ekonomi.Universitas Diponegoro Semarang.Vol. 36. No.11.pp.919-940

9. Made Rendy.dan Wayan Santika. 2014. Pengaruh Persepsi Kemudahan Penggunaan, Kegunaan Yang Dirasakan, and Tingkat Pendidikan Terhadap Niat Berbelanja Kembali Pada Situs Tokobagus.Com. E-Jurnal Ekonomi and Bisnis. Universitas Udayana Vol. 5 No. 9. Pp.2815-2833

10. Piriyakul, M., R. Piriyakul., O. Chuachareon., M. Boonyoung., P. Piriyakul., I. Piriyakul. 2015. "Effects of Trust, Satisfaction and Factors Corresponding to TAM on Intention to Reuse Internet Business Transaction" International Review of Management and Business Research. Vol. 4 No. 3.pp. 344-358

11. Ratu olivia. 2012. Faktor - faktor yang Mempengaruhi Minat Penggunam E-Commerce dengan Menggunakan Technology Acceptance Model (TAM). Surabaya: Sekolah Tinggi Ilmu Ekonomi Perbanas. Vol. 17.No. 2.pp 96-113

12. Regina., Andini., and Ayu. 2015. Implementasi Program Posyandu Menggunakan Technology Acceptance Model (TAM). Jurnal Fisip Unpar.Vol. 2.No. 3.pp. 1-8

13. Rocker, C. (2009).Perceived Usefulness And Perceived Easy-Of-Use Of Ambient Intelligence Applications In Office Environments. In: M, Kuroso(Ed.): Human-Centered Design, HCII 2009, LNCS 5619. Springer Verlag, Heidelberg, Germany, Pp. 1052-1061.

14. Saputro.dan Sukirno. 2013. Pengaruh Persepsi Kemudahan Penggunaan, Kepercayaan, Kecemasan Berkomputer and Kualitas Layanan Terhadap Niat Menggunakan Internet. Jurnal Manajemen Ekonomi and Bisnis.Vol. 16.No. 1.pp. 44-52

15. Wahyuningtyas., and Widiastuti. 2015. Analisis Pengaruh Persepsi Risiko, Kemudahan and Manfaat Terhadap Niat Pembelian Secara Online (Studi Kasus Pada Konsumen BarangFashion Di Facebook). Jurnal Kajian Bisnis, Vol. 23, No. 2.pp. 34-45 